\title{
ДВЕ КНИГИ ОДНОГО ПРОФЕССОРА
}

Тузмухамедов P.A. Право национальных меньшинств, Уфа: «Восточный университет», 1996. - 127 с.

«Права народов. Международно-правовой толковый словарь». Составление и общая редакция профессора P.A.Tуз. мухамедова. - Уфа: «Восточный университет», 1996. $124 \mathrm{c}$.

В течение нескольких последних лет профессор Р.А.Тузмухамедов последовательно разрабатывает и пропагандирует тему прав народов. В Уфе и Казани, в Москве и Ташкенте выходят его публикации на эту тему. Он частый гость у нас в Башкирии и в Казани с лекциями по этим вопросам. Не случайно именно в Казани в прошлом году вышла его книга «Права и свободы народов» (см. МЖМП, 1995, № 4, рецензия Хакимова).

И вот в Уфе в феврале-апреле с.г. вышли одна за другой две новые монографии профессора. Одна из них - «Право национальных меньшинств» имеет посвящение «К 70-летию автора». Для меня эта цифра была неожиданной. Мы встречаемся в каждый приезд Раиса Абдулхаковича в Башкирию. Никогда не думал, что он берет такой рубеж...

Взявшись за проблему прав народов, профессор расширяет в 1995 году плацдарм своих исследований, включая в них теперь и вопрос о правах национальных меньшинств. Еще до выхода отдельной книги по данной теме он опубликовал серию статей*. Более того, издал в Казани и Москве два законопроекта: «Об уполномоченном о правах народов Российской Федерации» (газета «Татарские края», Казань, август 1995 г., № 30) и «Об обеспечении прав национальных меньшинств в Республике Татарстан» (газета «Татарские новости», Москва, № 12/22/1995 г. и журнал «Панорама-Форум», Казань, 1995 г., № 3). Он - один из разработчиков законопроекта Госдумы РФ «О национальных меньшинствах в Российской Федерации». Его доклад об этих меньшинствах лег в основу парламентских слушаний Госдумы 20 июня 1995 г. о проекге Федерального закона «О защите национальных меньшинств» (см. издание Государственной Думы «Материалы парламентских слушаний», 1996 г.).

И вот теперь отдельная монография.

Если взять и прошлогоднюю, и две книги этого года, то их ббъединяет то, что сам профессор на других парламентских слушания X - 19 марта с.г. - назвал в своем докладе «этническими правами в международном праве». Он тогда даже дал определение этим пра-

* Последнюю см. «Государство и право». - 1995. - № 2. 
вам: «Это права этнических общностей, а тӓкје отдельных лиц, принадлежащих $\mathbf{x}$ ним, связанные и устанавливаемые в связи с их этнической самобытностью и направленные на защиту их по причине такой самобытности».

Словарь «Права народов» содержит почти 120 терминов, из коих более половины описаны самим Р.А.Тузмухамедовым. Базой словаря стал другой, составленный им совместно с профессором В.И.Кузнецовым и выпущенный «Международными отношениями» ничтожным тиражом в 1993 г. «Словарь прав человека и народов». Но новый почти наполовину состоит из новых терминов, статьи о которых принадлежат перу профессора. Такой слфварь, насколько знаю из уст генерального секретаря Организации непредставленных стран и народов барона Майкла Ван Праага, единственный в мире (он собирается выпустить его на английском языке). Кстати, об этой любопытной организации в словаре тоже есть статья.

Лиха беда - начало. Хорошо бы продолжить работу над словарем. И тогда надо бы дополнить его словник за счет новых терминов. Думаю, $\mathbf{x}$ примеру, что в нем должны найти отражение Международная лига за права и освобождение народов, Международная организация по миграции, оба Гаагских трибунала (по Югославии и Руанде), Международный фонд за права и овобождение народов и т.д.

Надеюсь, что, коль скоро словарь посвящается Декаде ООН прав коренных народов, он привлечет внимание и в штаб-квартире ее, и в Центре по правам человека в Женеве. Там должны знать, сколь активно российские юристы-международники разрабатывают проблемы, важные для $\mathrm{OOH}$.

Почти столь же уникальна и вторая книга. Насколько знаю, у нас (в 1959 г. в Тбилиси) была опубликована единственная монография по проблемам национальных меньшинств. Это работа покойного Г.К.Жвания «Международно-правовые гарантии защиты национальных меньшинств». Она была, естественно, посвящена анализу деятельности только Лиги Наций.

Р.А.Тузмухамедов анализирует сегодняшнее положение. Там нет перечня прав и пересказа. Все это вынесено автором в большое приложение, содержащее все основные как международно-правовые, так и национальные источники. Таким образом, приложение само по себе чрезвычайно полезный источник справок для тех, кто интересуется проблемой. Зато в работе содержатся рассуждения автора и его собственные подходы как эксперта.

Работа важна для нынешней российской ситуации и теоретически, и практически. В ней сжато обобшены изыскания как отдельных западных специалистов, так и длительная работа Подкомиссии Комиссии ООН по правам человека по предупреждению дискримина- 
ции и защите меньшинств. Она базируется на всех основных мехдународно-правовых, а также национально-законодательных источниках (европейских государств). Автор обеспечил перевод, отредактировал и опубликовал в приложении и Рамочную конвенцию о защите национальных меньшинств, отхрытую Советом Европы для подписания 1 февраля 1995 г., которую Россия подписала в день своего официального вступления в Совет 28 февраля 1996 г.

Такую исследовательскую базу Р.А.Тузмухамедов использет и для того, чтобы приложить ее к российской действительности. Главная ее черта в этом отношении состоит, как известно, в том, что развал СССР резко усложнил картину. Если раньше национальньми меньшинствами, по мехдународным стандартам, были у нас те лица и этнические группы, которые имели свои государства вне Союза, то с конца 1991 года число таких общностей резко возросло - национальными меньшинствами оказались и этнические представители народов, давших титульное наименование новым государствам на территории бывшего СССР. Одновременно в связи в уверенизацией автономных республик в составе Российсксй Федерации возникли меньшинства (точнее - оказались формально в таком качестве) от «титульных наций» этих государственных образований. Для Москвы проблема резко обострилась политически в связи с тем, что Беловежские соглашения трех (8 декабря 1991 г.), а затем и Алма-Атинская декларация одиннадцати (21 декабря 1991 г.) совершенно не просчитанно оставили вне России более 20 млн. русских, которых надо, как оказалось, зашищать. Выяснилось постепенно, что лучший путь - добиться от новых государств признания и закрепления для них статуса национальных менышинств, ибо статус двойного грахданства за ними никто, кроме Туркмении, так и не захотел признать (впрочем, это доказала и долгая практика международного права).

Короче, то, как Россия решит проблему национальных меньшинств у себя, отразится и на судьбах русских в других странах СНГ. Но это решение теперь зависит и от аккуратного подхода к проблеме, связанной с новой государственностью более трети национально-территориальных субъектов самой Российской Федерации. Очень показателен в этом отношении пример моей Республики Башкортостан. По численности у нас на первом месте стоят русские, на втором татары. И лишь на третьем месте (около 20\%) - сами башкиры. Если подходить по представлениям советских времен, когда национальными меньшинствами («нацменами») Москвой считались все, кого меньше, чем русских, то башкиры должны считаться национальным меньшинством в собственной республике. То же относится $\mathrm{x}$ якутам в Саха (Якутии), тувинцам в Туве и т.д.

Или взять другой аспект этой же проблемы. Татар вне Татарстана, но в России хивет почти втрое больше. Где они «национальное 
меньшинство»? В связи с этим и другой вопрос: решает ли проблему национальных меньшинств лишь предоставление им национально-культурной автономии, как считали и считают до сих пор в Миннаце России? Или следует, учитывая мировую практику (Венгрия, Румыния, Словения и т.д.), а также наше собственное прошлое (немцы Поволжья, еврейская автономия и т.п.), иметь в виду, что в случаях компактного проживания национальных меньшинств они должны иметь право и на создание своих территориальных административных образований?

Мне кахется, что на эти вопросы позитивно отвечал закон, принятый весной 1993 года Верховным Советом РФ, но так и не подписанный Президентом. Сегодня, по моему убеждению, удачно то определение, которое дает, приведя и проанализировав другие, автор книги. Вот оно: «Национальное меньшинство - это часть этноса, состоящая из грахдан данного государства, проживающих в нем постоянно, как компактно, так и дисперсно, имеющих или не имеющих свое национально-государственное образование вне данного государства или национально-территориальную единицу в рамках данного государства, отличающихся от остального населения государства своего грахданства этнически, языком, самобытной культурой и объединенных общим самоназванием и единым этническим самосознанием» (с.21). Думаю, что такое определение было бы весьма удачным и для зашиты прав русских, оставшихся после 1991 года вне нынешней России.

Ничего кроме благодарности Раису Абдулхаковичу за эту его монографию, равно как и за словарь, не могу не высказать. В связи с тем что из своих 70 лет он более полувека отдал мехдународному праву, наиболее влиятельный общественно-политический казанский журнал «Панорама-Форум» и единственный ташкентский правовой журнал «Хаёт ва хукук» («Жизнь и право») посвятили ему специальные номера. В Ташкенте и Уфе вышли юбилейные брошюры о профессоре*. Его труд приветствовал Генеральный секретарь ООН профессор Буртос Бутрос Гали.

Присоединяюсь К потоку приветствий этой рецензией. Спасибо Вам, Учитель!

Х.А.Т и м е ршин н доцент, кандидат юридических наук, заведуюший кафедрой Юридического института МВД Башкортостана

* Наш журнал в № 4 за 1992 год опубликовал научно-биографическую статью о профессоре Р.A. Тузмухамедове. 